\title{
Can the efficacy of in-office tooth bleaching change in the presence of orthodontic
}

\section{brackets? An in vitro study}

Clareamento dental in office durante o uso de bráquete ortodôntico pode alterar sua eficácia? Estudo invitro

El blanqueamiento dental en la oficina durante el uso de pulsera ortodóntica ¿puede cambiar su efectividad? Estudio invitro

Received: 03/03/2021 | Reviewed: 03/07/2021 | Accept: 03/24/2021 | Published: 04/02/2021

\author{
Lycia Gardenia dos Santos Oliveira \\ ORCID: https://orcid.org/0000-0001-7681-2871 \\ Federal University of Sergipe, Brazil \\ E-mail: Lycia_gso@hotmail.com \\ Luciana Fávaro Francisconi-dos-Rios \\ ORCID: https://orcid.org/0000-0002-9581-7544 \\ University of São Paulo, Brazil \\ E-mail luff@usp.br \\ Leandro de Moura Martins \\ ORCID: https://orcid.org/0000-0002-2469-0291 \\ Federal University of Amazonas, Brazil \\ E-mail: martins.1.m@gmail.com \\ Flávia Pardo Salata Nahsan \\ ORCID: https://orcid.org/0000-0002-3547-8886 \\ Federal University of Sergipe, Brazil \\ E-mail: flavia_odonto@hotmail.com
}

\begin{abstract}
Objective: To assess the color change of bovine enamel after tooth bleaching while using orthodontic brackets. Methodology: This in vitro study selected 48 bovine incisors without visible fractures or cracks (cut in blocks of $8 \times 12 \times 3 \mathrm{~mm}$ ). They were distributed in four groups: no staining and with brackets (NSWB), no staining and no brackets (NSNB), with staining and brackets (WSWB), and with staining and no brackets (WSNB) $(\mathrm{n}=12)$. The color was initially assessed with a spectrophotometer for NS (no staining). The teeth in WS (with staining) groups were immersed in an instant coffee solution for 15 days and the initial color was also assessed. After prophylaxis and adhesive treatment, the brackets were bonded to the teeth. The teeth were bleached with $35 \%$ hydrogen peroxide and the color was analyzed 30 days after bleaching. A two-way Analysis of Variance was applied as well as a subsequent multiple comparison analysis ( $>0.05)$. Results: According to the data obtained, the factor of the presence of brackets $(\mathrm{p}=0.569)$ had no significant influence. This differed from the factor of tooth staining $(\mathrm{p}<0.001)$. Moreover, there was no interaction between them $(\mathrm{p}=0.863)$. Conclusion: The presence of brackets in non-stained teeth did not affect bleaching effectiveness. The $\Delta \mathrm{E}$ of stained teeth was always lower than non-stained teeth, especially for the NB (no brackets) group.
\end{abstract}

Keywords: Bleaching agents; Tooth bleaching; Orthodontics.

\section{Resumo}

Objetivo: Avaliar alteração de cor do esmalte bovino após o clareamento dentário com o uso de bráquetes ortodônticos. Metodologia: Neste estudo in vitro, 48 incisivos bovinos, sem fraturas ou trincas visíveis (cortados em blocos de 8X12X3mm) foram selecionados. Estes foram distribuídos em quatro grupos: grupo sem manchamento com bráquete (SMCB), grupo sem manchamento sem bráquete (SMSB), grupo com manchamento com bráquete (CMCB) e grupo com manchamento sem bráquete (CMSB) $(n=12)$. A cor foi avaliada inicialmente com espectrofotômetro para SM (sem manchamento), os dentes dos grupos CM (com manchamento) foram imersos em solução de café solúvel por quinze dias e cor inicial também avaliada. Após a profilaxia e tratamento adesivo, os dentes tiveram os bráquetes colados. Os dentes foram submetidos ao clareamento com peróxido de hidrogênio a $35 \%$ e a cor foi analisada após 30 dias do clareamento. O teste aplicado foi Análise de Variância a 2 critérios e uma subsequente análise de comparações múltiplas ( $\mathrm{p}>0,05)$. Resultados: De acordo com os dados obtidos, $\mathrm{O}$ fator presença de bráquetes $(\mathrm{p}=0,569)$ não exerceu influência significante. Diferentemente do fator manchamento dentário $(\mathrm{p}<0,001)$. Ademais, não houve interação entre eles $(\mathrm{p}=0,863)$. Conclusão: A presença de bráquete em dente não manchado não afetou a efetividade do clareamento. $\mathrm{O} \Delta \mathrm{E}$, quando houve manchamento dentário, foi sempre inferior que aquele quando não houve manchamento, principalmente para o grupo SB (Sem Bráquete). 
Palavras-chave: Clareadores; Clareamento dental; Ortodontia.

\section{Resumen}

Objetivo: Evaluar el cambio de color del esmalte bovino tras el blanqueamiento dental mediante brackets de ortodoncia. Metodología: En este estudio in vitro se seleccionaron 48 incisivos bovinos, sin fracturas ni fisuras visibles (cortados en bloques de $8 \mathrm{X} 12 \mathrm{X} 3 \mathrm{~mm}$ ). Estos se dividieron en cuatro grupos: grupo sin tinción de brackets (SMCB), grupo sin tinción de brackets (SMSB), grupo con tinción de brackets (CMCB) y grupo con tinción de brackets $(\mathrm{CMSB})(\mathrm{n}=12)$. El color se evaluó inicialmente con un espectrofotómetro para SM (sin tinción), los dientes de los grupos CM (con tinción) se sumergieron en solución de café soluble durante quince días y también se evaluó el color inicial. Después de la profilaxis y el tratamiento adhesivo, los brackets se adhirieron a los dientes. Los dientes se blanquearon con peróxido de hidrógeno al 35\% y se analizó el color 30 días después del blanqueamiento. La prueba aplicada fue Análisis de Varianza con 2 criterios y posterior análisis de comparaciones múltiples ( $\mathrm{p}>0.05$ ). Resultados: Según los datos obtenidos, el factor de presencia de brackets $(\mathrm{p}=0,569)$ no tuvo una influencia significativa. A diferencia del factor de tinción dental ( $\mathrm{p}<0,001)$. Además, no hubo interacción entre ellos ( $\mathrm{p}=0,863$ ). Conclusión: La presencia de brackets en dientes no contaminados no afectó la efectividad del blanqueamiento. El $\Delta \mathrm{E}$, cuando hubo tinción dentaria, fue siempre menor que cuando no hubo tinción, principalmente para el grupo SB (Sin Bracket).

Palabras clave: Blanqueamiento; Blanqueamiento dental; Ortodoncia.

\section{Introduction}

Considering extrinsic stains, the constituents of the human diet change tooth color in different ways, often because of the association of salivary proteins with components of these foods, such as polyphenols (Proctor et al., 2005). Some beverages rich in polyphenols, such as tea, wine, and coffee, produce color changes in teeth over time, which is affected by the low $\mathrm{pH}$ and the color of such foods. Tooth bleaching is one of the treatment options to solve or minimize tooth staining (Brook et al., 2007; Hattab et al., 1999; Nathoo, 1997; Sulieman, 2005).

Theoretically, the diffusion of hydrogen peroxide in the bleaching gel occurs due to the oxidation caused by the products resulting from its decomposition. Thus, low-weight molecules diffuse through the dental tissues in alkaline conditions, breaking chromophores into molecules of lower complexity that reflect less light (Araújo et al., 2010; Consolaro et al., 2013; Eimar et al., 2012; Goldberg et al., 2010; Joiner, 2006; Markowitz, 2010; Thiesen et al., 2013), bleaching the teeth (Gomes et al., 2017; Jadad et al., 2011; Montenegro-Arana et al., 2016).

It is mentioned that using brackets may prevent/decrease the diffusion of hydrogen peroxide through the adjacent enamel (Castro et al., 2017; Consolaro et al., 2013; Lunardi et al., 2014). However, authors have shown that teeth can be bleached satisfactorily even in the presence of orthodontic brackets, in comparison to bleaching without brackets, without presenting an aesthetic loss (Gomes et al., 2017; Jadad et al., 2011; Montenegro-Arana et al., 2016). Jadad et al. (2011) compared the tooth bleaching treatment with and without brackets using $8 \%$ hydrogen peroxide and showed that the product was effective with a similar degree of bleaching in both cases, which suggests the occurrence of diffusion under the brackets (Jadad et al., 2011).

Scientific evidence has shown that teeth can be bleached while using orthodontic appliances (Castro et al., 2017; Feitosa et al., 2020; Gomes et al., 2017; Jadad et al., 2011; Lunardi et al., 2014; Montenegro-Arana et al., 2016). Such procedure would allow performing esthetic restorations immediately after removing the brackets, accelerating the esthetic conclusion of the case (Castro et al., 2017; Gomes et al., 2017; Lunardi et al., 2014; Márquez et al., 2012; Shibasaki et al., 2019). It would also promote better acceptance of the orthodontic treatment among patients who are reluctant to use brackets (Jadad et al., 2011) and optimize hygiene and the search for more esthetic procedures due to the lighter tooth surface (Bulut et al., 2006; Christensen, 1997).

Considering that the mode of diffusion of bleaching agents in the scientific literature is not fully explained, as there are only theories about the true mechanism of gel propagation through the teeth (Benetti et al., 2004; Eimar et al., 2012; Kwon 
\& Wertz, 2015), and that the possibility of finishing an orthodontic treatment with teeth already aligned and bleached may encourage patients to accept the treatment sequence (Gomes et al., 2017), new studies have been required to show bleaching efficacy while using orthodontic brackets.

\section{Methodology}

This work corresponded to an in vitro study that assessed color change $(\Delta \mathrm{E})$ in bovine enamel caused by artificial staining (I- coffee immersion and II- deionized water immersion) and the subsequent tooth bleaching (TB) in the treatment with orthodontic bracket bonding, performed in a laboratory with 48 bovine incisors selected for the study. The $\Delta \mathrm{E}$ values were measured as reference/baseline.

In this experimental research, the variable of main response involved the analysis of color changes that occurred under orthodontic brackets after tooth bleaching in enamel when it was still cemented.

Forty-eight bovine incisors were selected. Teeth of approximate size were included and teeth with visible crown fractures or cracks in the direct visual assessment were excluded. All teeth were stored in saline solution at room temperature.

Based on previous studies and using the IBM SPSS Statistics for Windows software (Version 27.0. Armonk, NY: IBM Corp), the mean standard deviation of 2.65 was used to calculate the sample. By using a 5\% significance level and $80 \%$ test power to detect a minimal difference of 4.40 of color change among the groups, at least 10 specimens per group were required (Bittencourt, 2014; Castro et al., 2017; Lunardi et al., 2014). It was decided to use 12 specimens per group, preventing potential complications that may exclude some specimens, not reaching the minimum number.

The bovine teeth were cut in dental crown blocks of $8 \mathrm{~mm} \times 12 \mathrm{~mm}$ of length with approximately $3 \mathrm{~mm}$ of thickness, using a double diamond disc (KG Sorensen, Rio de Janeiro, RJ, Brazil) at low rotation and under constant water cooling. The thicknesses were verified with a digital caliper (Digimess, São Paulo, SP, Brazil). The enamel surface was flattened with carborundum discs (\#320, 600, and $1200 \mathrm{Al}_{2} \mathrm{O}_{3}$ discs; Buehler, Lake Bluff, IL, USA), which resulted in the removal of approximately $100 \mu \mathrm{m}$ of depth. Polishing was performed with a silicon carbide polishing tip (American Burrs, Palhoça, SC, Brazil), a felt disc, and diamond paste, at low rotation for 20 seconds.

The specimens were distributed equally in four groups with a simple allocation through a random draw of numbers 1 through 48, using envelopes according to the treatment (NS- no staining, WS- with staining, WB- with bracket, NB- no bracket).

The teeth in the artificial staining group were immersed in a coffee solution prepared with $25 \mathrm{~g}$ of instant coffee (Nescafé Tradição, Nestlé Brasil Ltda., Araras, SP, Brazil) and $100 \mathrm{~mL}$ of distilled water at room temperature (Torres et al., 2013) for 15 days. The solution was changed every 24 hours and the specimens were washed at each exchange.

Fifteen days after tooth staining in the WS group, prophylaxis was performed with pumice and Robinson brush in the dental blocks, as well as cleaning with water spray.

For bracket bonding, a 37\% phosphoric acid (Condac - FGM) etching was performed in the enamel for 30 seconds at the site of accessory bonding, abundantly washed for 60 seconds, and dried by air blast. The Transbond ${ }^{\mathrm{TM}} \mathrm{XT}$ adhesive (3M Unitek, Landsberg, Germany) was applied and light-cured for 20 seconds with the Radii-cal device (SDI, Victoria, Australia). Next, stainless steel orthodontic metal brackets, Roth prescription (Morelli, Sorocaba, SP, Brazil) were bonded. They were assigned to upper right central incisors, slot 0.22 , with Transbond ${ }^{\mathrm{TM}} \mathrm{XT}$ resin (3M Unitek, Landsberg, Germany). The resin excess was removed with an orthodontic spatula and the set was polymerized for 20 seconds. The specimens were stored in 0.5 $\mathrm{mL}$ of deionized water, in a lidded plastic box, at room temperature, for 24 hours.

A single evaluator read the specimens with an X-Rite Color 962 spectrophotometer (Danaher Corporation, Michigan, USA) of color reflectance. The measurement was performed and repeated three times and a mean of the values was calculated. 
The measures were taken at three different times: 1- Before the procedures; 2- After staining; and 3- Thirty days after bleaching. The spectrophotometer was calibrated according to the manufacturer's specifications, using SAV (small area variation) of $3 \mathrm{~mm}$.

Each specimen was marked with a black nail polisher (Colorama, Rio de Janeiro, Brazil) on the posterior surface to standardize the specimen number during the color assessment.

For the readings after bleaching, the brackets were removed with bracket remover orthodontic pliers \#346R (ICE, São Paulo, SP, Brazil). The remaining resin was removed with a multilaminated low-rotation zirconia drill (Morelli, Sorocaba, SP, Brazil) and polishing was performed with a silicon carbide polishing tip (American Burrs, Palhoça, SC, Brazil). Next, the teeth were stored in deionized water to rehydrate the enamel for 24 hours as aforementioned.

In the bracket location (research interest area), a matrix with a 3-mm hole was placed to reduce the size of the reading point of the spectrophotometer.

For color assessment, the model proposed by the Commission Internationale de l'Eclairage (CIE) $\mathrm{L}^{*} \mathrm{a}^{*} \mathrm{~b}^{*}$ was used. Measuring the color differences $[\Delta \mathrm{E}]$ obtained after bleaching the dental blocks required using formulas recommended by the CIE method: $\Delta \mathrm{E}=\sqrt{ }[\Delta \mathrm{L}]^{2}+[\Delta \mathrm{a}]^{2}+[\Delta \mathrm{b}]^{2}$, where $\Delta \mathrm{L}=\mathrm{L} 1[$ final] $-\mathrm{L} 0$ [initial], $\Delta \mathrm{a}=\mathrm{a} 1$ [final] $-\mathrm{a} 0$ [initial], $\Delta \mathrm{b}=\mathrm{b} 1$ [final] b0 [initial]. This system presents $\mathrm{L}^{*}$ as the luminosity variable and $\mathrm{a}^{*}$ and $\mathrm{b}^{*}$ as the chromaticity coordinates, with ranges of $\mathrm{a}^{*}$ between green (-) and red (+) and $\mathrm{b}^{*}$ between blue (-) and yellow (+).

One day after staining and 24 hours after bracket bonding on the buccal surface, the specimens were subjected to the first high-concentration tooth bleaching session with 35\% hydrogen peroxide Total Blanc Office (DFL, Rio de Janeiro, RJ, Brazil), following the manufacturer's instructions: applying three times for 15 minutes/session, three sessions (once/week). After bleaching, the specimens were washed to fully remove the bleaching agent and stored in $0.5 \mathrm{ml}$ of deionized water, in a lidded plastic box, at room temperature, for 30 days. The water was changed daily.

Color analyses were performed 30 days after bleaching as described previously.

Regarding the response variable (continuous quantitative), two-way Analysis of Variance and subsequent multiple comparison analysis was used at a 5\% significance level. The SigmaPlot 13 statistical software (Systat Software, Inc., San Jose, CA, USA) was used.

\section{Results}

The analysis of the data obtained shows that, differing from the presence of brackets $(\mathrm{p}=0.569)$, the factor of tooth staining significantly affected the results $(\mathrm{p}<0.001)$. Moreover, there was no interaction between them $(\mathrm{p}=0.863)$.

Table 1 describes the mean $\Delta \mathrm{E}$ values (CIELab, 30 days after treatment minus initial condition) of the enamel with brackets (WB) or no brackets (NB), and with staining (WS) or no staining (NS).

Table 1 - Mean \pm standard deviation of $\Delta \mathrm{E}$ values (CIELab, 30 days after treatment minus initial condition) of the enamel with brackets (WB) or no brackets (NB), and with staining (WS) or no staining (NS).*

$$
\text { NB WB }
$$

\begin{tabular}{|l|l|l|}
\hline NS & $11.00 \pm 2.91^{\mathrm{Aa}}$ & $11.29 \pm 3.36^{\mathrm{Aa}}$ \\
\hline WS & $8.18 \pm 0.97^{\mathrm{Ba}}$ & $8.70 \pm 0.93^{\mathrm{ABa}}$ \\
\hline
\end{tabular}

*Different upper-case letters indicate a statistically significant difference $(\mathrm{p}<0.05)$ in each column for the factor of tooth staining (NS, WS). Different lower-case letters indicate a statistically significant difference $(\mathrm{p}<0.05)$ for the factor of the presence of brackets $(\mathrm{NB}$, WB). Source: Authors. 
The results obtained (Table 1) confirm the color change in bovine teeth with and without brackets subjected to inoffice bleaching after 30 days. The null hypothesis that the use of orthodontic brackets and staining did not affect the color change and stability of bovine teeth after 30 days should therefore be rejected.

\section{Discussion}

Considering teeth with and without brackets and not stained, tooth bleaching was effective. Thus, there is evidence that hydrogen peroxide penetrated the enamel and permeated the dentin, bleaching the structures. The hydrogen peroxide molecule presents a very low molecular weight (34 mg Mol) (Kugel et al., 2007) and perhaps this is why it is one of the chemical molecules with the highest penetrating power in the tooth structure. When applied close to orthodontic brackets, it penetrates the subsurface, thus bleaching the tooth structure (Consolaro et al., 2013). Theoretically, its penetration produces free radicals that are conducted multi/polydirectionally, thus working under resin restorations and orthodontic brackets (Jadad et al., 2011). Conversely, the scientific literature reports that areas covered by gingiva or in contact with another tooth will not receive the bleaching agent as equally as uncovered areas, producing a high risk of irregularities in color and staining (Consolaro et al., 2013). It is also mentioned that, after removing the orthodontic bracket, the enamel presents irregular surface and color (Consolaro et al., 2013; Lunardi et al., 2014), and it is not known whether hydrogen peroxide works uniformly through the adamantine fluid (Ayres et al., 2016; Consolaro et al., 2013).

Nonetheless, the present study used a high-concentration gel (Araújo et al., 2010; Ayres et al., 2016; Feitosa et al., 2020; Gomes et al., 2017; Horning et al., 2013; Lima et al., 2020; Lunardi et al., 2014), which increases the penetration power of the product in the tooth enamel (Abouassi et al., 2011; Benetti et al., 2004; Bistey et al., 2007) despite reports of lowconcentration formulations (Jadad et al., 2011; Montenegro-Arana et al., 2016) that were also effective.

Even with the use of a $35 \%$ hydrogen peroxide bleaching gel, when comparing the group with and without staining, the group with staining presented lower $\Delta \mathrm{E}$ values than the group without staining, particularly the WSNB group. A probable justification for the non-stained group to have presented a greater color difference can be the insufficient gel application. Another hypothesis is that coffee staining would have made it difficult for the teeth to obtain bleaching as effectively as those immersed only in water. Considering that all diets are somehow pigmented but not homogeneously, the degree of staining would be a factor worth considering when deciding on bleaching with brackets in more pigmented teeth. Moreover, the variation of the amount of enamel and dentin between the specimens may have contributed, considering that factors such as the thickness of dentin, enamel, and cement affect the penetration of the hydrogen peroxide molecule. The higher the amount of tooth structure, the lower the diffusion of the bleaching agent (Palo et al., 2012).

Coffee staining was performed as a way to compare the groups with more and less visible extrinsic stains, aiming to simulate the accumulation of food pigments adhered for the stained group. Hence, the specimens were pigmented with coffee, similar to Araújo (2010) and Torres et al (2013), for 15 days. Another product that is extensively used for the same purpose is black tea (Castro et al., 2017; Joiner et al., 2003; Lunardi et al., 2014).

To assess this color change, a spectrophotometer was used (Araújo et al., 2010; Castro et al., 2017; Eimar et al., 2012; Feitosa et al., 2020; Jadad et al., 2011; Lunardi et al., 2014; Montenegro-Arana et al., 2016) because it provides quantitative color information, which allows a more reliable comparison. Moreover, the CIELab protocol was used to assess the color, aiming to standardize the values found (Caneppele et al., 2013; Castro et al., 2017; Feitosa et al., 2020; Lunardi et al., 2014). Using the VITA scale with the equivalence of 16 colors in the guide with a numerical scale (Jadad et al., 2011; MontenegroArana et al., 2016) could produce a subjective assessment. 
Also for the use of the spectrophotometer, reducing the reading area (SAV) to $3 \mathrm{~mm}$ allowed a satisfactory visualization of color difference in the area under the brackets, which is an important decrease to show color heterogeneity, considering that a larger opening does not allow viewing this variation between both areas (Lunardi et al., 2014).

Enamel and dentin dehydration interferes with tooth color due to the change in the air/water refraction index. During bleaching, besides the relative isolation, the bleaching gel may affect tooth hydration, providing less water (Matis et al., 1998; Spalding et al., 2003). In the present study, to prevent dehydration and color change, the teeth were stored in distilled water (Castro et al., 2017), but another common type of storage could be artificial saliva (Lunardi et al., 2014; Pinheiro et al., 2011).

Some authors discuss, separately, the difference of L, a, and b values (Bengel, 2003; Caneppele et al., 2013; Dietschi et al., 2006). For Dietschi, Rossier, and Krejci (2006), a and b values, relative to saturation, would be less important, and the L value would be the most significant. The present study considers essential the total $\Delta \mathrm{E}$ value, which are rapidly perceptible values visible to the naked eye.

Considering the divergences of results and the small number of studies correlating tooth bleaching to the use of orthodontic brackets, further research is required to compare the effectiveness of high-concentration bleaching products during the orthodontic treatment and without using orthodontic appliances.

\section{Conclusion}

Based on the methodology used and the results obtained, it is concluded that tooth bleaching is effective even in the presence of orthodontic brackets. However, the degree of tooth staining should be assessed previously, considering it may be required to increase the number of hydrogen peroxide applications to obtain a satisfactory result.

Thus, performing randomized clinical trials is suggested to provide data that are increasingly safer for the dental clinic.

\section{References}

Abouassi, T., Wolkewitz, M., \& Hahn, P. (2011). Effect of carbamide peroxide and hydrogen peroxide on enamel surface: An in vitro study. Clinical Oral Investigations, 15(5), 673-680. https://doi.org/10.1007/s00784-010-0439-1

Araújo, R. M., Torres, C. R. G., \& Araújo, M. A. M. de. (2010). In vitro evaluation of dental bleaching effectiveness using hybrid lights activation. Revista Odonto Ciência, 25(2), 159-164. https://doi.org/10.1590/s1980-65232010000200010

Ayres, A. P. A., Berger, S. B., Carvalho, A. O., \& Giannini, M. (2016). Efeito do peróxido de hidrogênio na permeabilidade dental. Revista Brasileira de Odontologia, 73(2), 096-100. https://doi.org/10.18363/rbo.v73n2.p.096

Benetti, A. R., Valera, M. C., Mancini, M. N. G., Miranda, C. B., \& Balducci, I. (2004). In vitro penetration of bleaching agents into the pulp chamber. International Endodontic Journal, 37(2), 120-124. https://doi.org/10.1111/j.0143-2885.2004.00761.x

Bengel, W. M. (2003). Digital Photography and the assessment of therapeutic results after bleaching procedures. Journal of Esthetic and Restorative Dentistry, $15(1), \mathrm{S} 21-\mathrm{S} 32$.

Bistey, T., Nagy, I., Simo, A., \& Hegedus, C. (2007). In vitro FT-IR study of the effects of hydrogen peroxide on superficial tooth enamel. Journal of Dentistry, 35, 325-330. https://doi.org/10.1016/j.jdent.2006.10.004

Bittencourt, C. de V. (2014). Eficácia de agentes clareadores em dentes com bráquetes ortodônticos. Universidade Federal do Espírito Santo.

Brook, A. H., Smith, R. N., \& Lath, D. J. (2007). The clinical measurement of tooth colour and stain. International Dental Journal, 57(5), 324-330. https://doi.org/10.1111/j.1875-595X.2007.tb00141.x

Bulut, H., Turkun, M., \& Kaya, A. D. (2006). Effect of an antioxidizing agent on the shear bond strength of brackets bonded to bleached human enamel. American Journal of Orthodontics and Dentofacial Orthopedics, 129(2), 266-272. https://doi.org/10.1016/j.ajodo.2004.03.043

Caneppele, T. M., Borges, A. B., \& Torres, C. R. (2013). Effects of dental bleaching on the color, translucency and fluorescence properties of enamel and dentin. The European Journal of Esthetic Dentistry : Official Journal of the European Academy of Esthetic Dentistry, 8(2), 200-212.

Castro, C. M. L. de, Borges, H. C. P., Barros, K. C. F., Santos, N. B. dos, \& Fragoso, L. S. de M. (2017). Spectrophotometric assessment of tooth bleaching under orthodontic braquets bonded with different materials. Revista de Odontologia Da UNESP, 46(5), 267-272. https://doi.org/10.1590/1807-2577.03617 
Christensen, G. J. (1997). Bleaching teeth: practitioner trends. The Journal of the American Dental Association, 128(April), 16S-18S. https://doi.org/10.14219/jada.archive.1997.0417

Consolaro, A., Consolaro, R. B., \& Francischone, L. (2013). Clarifications, guidelines and questions about the dental bleaching "associated" with orthodontic treatment. Dental Press Journal of Orthodontics, 18(5), 4-10. https://doi.org/10.1590/s2176-94512013000500002

Dietschi, D., Rossier, S., \& Krejci, I. (2006). In vitro colorimetric evaluation of the efficacy of various bleaching methods and products. Quintessence International, 37(5), 515-526. https://doi.org/10.1016/j.prosdent.2006.09.009

Eimar, H., Siciliano, R., Abdallah, M. N., Nader, S. A., Amin, W. M., Martinez, P. P., Celemin, A., Cerruti, M., \& Tamimi, F. (2012). Hydrogen peroxide whitens teeth by oxidizing the organic structure. Journal of Dentistry, 40(2), e25-e33. https://doi.org/10.1016/j.jdent.2012.08.008

Feitosa, F. de S. Q., Cabral, H. do S. R., Feitosa Filho, A., Borges, F. de S. Q., Feitosa, H. A., Costa, L. E. D., Santos, A. J. S., \& Praxedes Neto, O. J. (2020). Clareamento dental durante o tratamento ortodôntico: efetividade e efeito sobre a resistência adesiva. Research, Society and Development, 9(8), 1-20.

Goldberg, M., Grootveld, M., \& Lynch, E. (2010). Undesirable and adverse effects of tooth-whitening products : a review. Clinical Oral Investigations, 14, 110. https://doi.org/10.1007/s00784-009-0302-4

Gomes, M. N., Dutra, H., Morais, A., Sgura, R., \& Devito-Moraes, A. G. (2017). In-Office Bleaching During OrthodonticTreatment. Journal of Esthetic and Restorative Dentistry, 29(02), 83-92.

Hattab, F. N., Qudeimat, M. A., \& Al-Rimawi, H. S. (1999). Dental discoloration: An overview. Journal of Esthetic and Restorative Dentistry, 11(6), 291310. https://doi.org/10.1111/j.1708-8240.1999.tb00413.x

Horning, D., Gomes, G. M., Bittencourt, B. F., Ruiz, L. M., Reis, A., \& Gomes, O. M. M. (2013). Evaluation of human enamel permeability exposed to bleaching agents. Brazilian Journal of Oral Sciences, 12(2), 114-118. https://doi.org/10.1590/s1677-32252013000200009

Jadad, E., Montoya, J., Arana, G., Alfonso, L., Gordillo, A., Palo, R. M., \& Loguercio, A. D. (2011). Spectrophotometric evaluation of color alterations with a new dental bleaching product in patients wearing orthodontic appliances. American Journal of Orthodontics and Dentofacial Orthopedics, $140(1)$, e43-e47. https://doi.org/10.1016/j.ajodo.2010.11.021

Joiner, A. (2006). The bleaching of teeth: A review of the literature. Journal of Dentistry, 34(7), 412-419. https://doi.org/10.1016/j.jdent.2006.02.002

Joiner, A., Elofsson, U. M., \& Arnebrant, T. (2003). Adsorption of chlorhexidine and black tea onto in vitro salivary pellicles, as studied by ellipsometry. European Journal of Oral Sciences, 111(1), 417-422. https://doi.org/10.1111/j.1600-0722.2006.00364.x

Kugel, G., Petkevis, J., Gurgan, S., \& Doherty, E. (2007). Separate Whitening Effects on Enamel and Dentin After Fourteen Days. Journal of Endodontics, 33(1), 34-37. https://doi.org/10.1016/j.joen.2006.07.012

Kwon, S. R., \& Wertz, P. W. (2015). Review of the mechanism of tooth whitening. Journal of Esthetic and Restorative Dentistry, $27(5), 240-257$. https://doi.org/10.1111/jerd.12152

Lima, C. C., Braga, L. L. A., Cunha, L. S., Dietrich, L., Martins, V. da M., \& Nascimento, F. (2020). Reanatomização estética do sorriso com auxílio de elásticos separadores: relato de caso. Research, Society and Development, 9(10), 1-13.

Lunardi, N., Correr, A., Rastelli, A., Lima, D. A. N. L., \& Consani, R. L. X. (2014). Spectrophotometric evaluation of dental bleaching under orthodontic bracket in enamel and dentin. J Clin Exp Dent, 6(4), e 321-e 326. https://doi.org/10.4317/jced.51168

Markowitz, K. (2010). Pretty painful: Why does tooth bleaching hurt? Medical Hypotheses, 74(5), 835-840. https://doi.org/10.1016/j.mehy.2009.11.044

Márquez, J. F., Pedroza-Garcés, A., \& Villada-Castro, M. (2012). Tooth bleaching before, during and after orthodontic treatment Aclaramiento dental, durante y después de ortodoncia. CES Odontologia, 25(2), 54-62.

Matis, B. A., Cochran, M. A., Eckert, G., \& Carlson, T. J. (1998). The efficacy and safety of a 10\% carbamide peroxide bleaching gel. Quintessence International (Berlin, Germany: 1985), 29(9), 555-563. http://www.ncbi.nlm.nih.gov/pubmed/9807138

Montenegro-Arana, A., Arana-Gordillo, L., Farana, D., Coelho, U., Davila-sanchez, A., Jadad, E., Gomes, O., \& Loguercio, A. (2016). Randomized Doubleblind Clinical Trial of Bleaching Products in Patients Wearing Orthodontic Devices. Operative Dentistry, 41(4), 379-387. https://doi.org/10.2341/15-240-C

Nathoo, S. A. (1997). The chemistry and mechanisms of extrinsic and intrinsic discoloration. Journal of the American Dental Association, 128(4), 6S-10S. https://doi.org/10.14219/jada.archive.1997.0428

Palo, R., Bonetti-Filho, I., Valera, M., Camargo, C., Camargo, S., Moura-Netto, C., \& Pameijer, C. (2012). Quantification of Peroxide Ion Passage in Dentin, Enamel, and Cementum After Internal Bleaching With Hydrogen Peroxide. Operative Dentistry, 37(6), 660-664. https://doi.org/10.2341/11-334-1

Pinheiro, H. B., Costa, K. G., Klautau, E. B., \& Cardoso, P. E. C. (2011). Análise microestrutural do esmalte tratado com peróxido de hidrogênio e carbamida. Rev Gaúcha Odontol., 59(2), 215-220.

Proctor, G. B., Pramanik, R., Carpenter, G. H., \& Rees, G. D. (2005). Salivary proteins interact with dietary constituents to modulate tooth staining. Journal of Dental Research, 84(1), 73-78. https://doi.org/10.1177/154405910508400113

Shibasaki, W., Integrada, O. O., Loiola, M., \& Dias, F. (2019). safe to perform tooth bleaching and orthodontic treatment at the same time? Clareamento dentário simultâneo ao tratamento ortodôntico é seguro? January, $0-4$.

Spalding, M., Taveira, L. A. de A., \& Assis, G. F. de. (2003). scanning electron microscopy study of dental enamel surface exposed to $35 \%$ Hydrogen Peroxide: Alone, with saliva, and with 10\% Carbamide peroxide. Journal of Esthetic and Restorative Dentistry, 15(3), 154-165. 
Research, Society and Development, v. 10, n. 4, e12410413513, 2021

(CC BY 4.0) | ISSN 2525-3409 | DOI: http://dx.doi.org/10.33448/rsd-v10i4.13513

http://www.ncbi.nlm.nih.gov/pubmed/6396635

Sulieman, M. (2005). An Overview of Tooth Discoloration: Extrinsic, Intrinsic and Internalized Stains. Dental Update, 32(8), $463-471$. https://doi.org/10.12968/denu.2005.32.8.463

Thiesen, C. H., Rodrigues Filho, R., Prates, L. H. M., \& Sartori, N. (2013). The influence of desensitizing dentifrices on pain induced by in-office bleaching. Brazilian Oral Research, 27(6), 517-523. https://doi.org/10.1590/s1806-83242013000600012

Torres, C. R. G., Perote, L. C. C. C., Gutierrez, N. C., Pucci, C. R., \& Borges, A. B. (2013). Efficacy of mouth rinses and toothpaste on tooth whitening. Operative Dentistry, 38(1), 57-62. https://doi.org/10.2341/11-360-L 